\title{
KOMUNIKASI BIMBINGAN ORANG TUA PADA ANAK DALAM UPAYA MENINGKATKAN PRESTASI BELAJAR MATEMATIKA
}

\author{
Oleh : \\ DENTI NOVIA SARI, LAMHIR SYAM SINAGA, EVI LORITA \\ Program Studi Ilmu Komunikasi Fakultas Ilmu-Ilmu Sosial Unived Bengkulu
}

\begin{abstract}
ABSTRACK
This study aimed to determine the children's parent communication in improving learning achievement in Mathematics. This was a qualitative descriptive research. Datas were collected by interviews, observation and documentation techniques. There were two groups of informants in this research, the key informant which consisted of a Math teacherin class VI Elementary School Number 27 Bengkulu and principal informant which consisted of two children's parent, Mrs. Desi Yanti and Lini Marlina. Communication messages done by parents in improving achievement in Mathematics subject were: (1) providing guidance and advice, (2) supervision of learning, (3) giving rewards and punishments, (4) the fulfillment of learning (5) creating condusive atmosphere in studying, (6) paying attention to children's health, and (7) providing handy hints. Based on the results of research and discussion, it was concluded that the instructional communication role of parents in improving learning achievement of Mathematics has been running quite well in pre-instructional stage and directing stage, also in follow-up evaluation stage. But in the aspect of instructional or learning it's not fully completed.
\end{abstract}

Keywords: communication between parents and children, achievement in Mathematics subject, instructional communication

\section{PENDAHULUAN}

Pada dasarnya, keberhasilan belajar seorang anak dalam hal ini prestasi belajar ditentukan oleh dua faktor yaitu faktor yang berasal dari dalam diri anak (internal) dan dari luar diri anak (eksternal). Faktor internal antara lain, faktor jasmani, kecerdasan/intelegensi, kedisiplinan, minat, bakat, motivasi, dan lain-lain. Sedangkan faktor eksternal berasal dari faktor sosial dan faktor non sosial. Faktor sosial mencakup lingkungan keluarga, lingkungan sekolah, dan lingkungan masyarakat. Interaksi dan komunikasi antar individu dalam ketiga lingkungan tersebut mempunyai pengaruh terhadap perilaku dan aktivitas belajar anak. Muhibbin Syah (2006).

Dalam lingkungan keluarga, orang tua mempunyai tanggung jawab penting dalam menumbuhkan semangat belajar anak. Pada usia sekolah dasar, anak masih membutuhkan pengawasan dan bimbingan belajar dari orang tua yang sangat ketat. Adanya bimbingan belajar orang tua dapat membantu mengarahkan anak dalam memecahkan masalah, mengawasi anak ketika belajar, mengarahkan waktu belajar dengan baik, membantu dalam menyediakan fasilitas belajar yang mendukung dengan pola komunikasi yang baik sehingga anak tidak merasa dibawah tekanan. Adanya intensitas bimbingan belajar yang tinggi dari orang tua akan membantu anak dalam mengatasi kesulitan belajar. Seperti halnya untuk mata pelajaran Matematika yang oleh sebagian besar anak tidak menyukainya. Bimbingan orang tua pada anak ketika belajar sangat diperlukan. Dengan demikian, anak dapat meningkatkan prestasi belajar di sekolah. 
Komunikasi bimbingan orang tua pada anak tanpa diikuti dengan komunikasi yang baik tidaklah berjalan sesuai dengan tujuan yang diharapkan. Komunikasi instruksional diciptakan secara wajar, akrab dan terbuka dengan ditunjang oleh faktorfaktor pendukung lainnya, baik sebagai sarana maupun fasilitas lain, dengan tujuan supaya mempunyai efek perubahan perilaku pada pihak sasaran. Orang tua (komunikator) dan anak (komunikan) samasama melakukan interaksi psikologis yang nantinya diharapkan bisa berdampak pada berubahnya pengetahuan sikap dan keterampilan dipihak komunikan. Proses interaksi psikologis ini berlangsung paling tidak antara dua orang dengan cara berkomunikasi. Dalam situasi formal maupun non formal, proses ini terjadi ketika sang komunikator berupaya membantu terjadinya proses perubahan tadi di pihak sasaran atau komunikan. Teknik atau alat untuk melaksanakan proses ini adalah komunikasi, yaitu komunikasi instruksional (Yusup, 2010). Komunikasi instruksional inilah diharapkan bimbingan orang tua pada anak dapat meningkatkan prestasi belajar anak terutama dalam pelajaran Matematika.

Komunikasi instruksional dalam bimbingan orang tua pada anak bisa berhasil dengan efektif hanya apabila komunikasi bisa berjalan atau berproses dengan baik. Oleh karena itu, kegiatan instruksionalnya yang dilakukan pada zaman informasi ini mendapat perhatian yang lebih dititik beratkan pada unsur sasaran didik dengan cara mengoptimalkan pemanfaatan sumbersumber informasi edukatif (sumber-sumber belajar) menurut Hart, Scott dan McCroskey dalam Yusup (2010). Komunikasi instruksional menurut Ricmond (2009) diartikan sebagai proses dimana pengajar membangun relasi komunikasi yang efektif dengan pelajar sehingga pelajar berkesempatan meraih keberhasilan yang maksimal dalam proses pembelajaran. Komunikasi instruksional yang efektif juga harus diikuti oleh komunikasi parenting Guru-Orang tua, Guru-Siswa/anak, Orang Tua- siswa/anak. Komunikasi parenting adalah suatu perilaku yang pada dasarnya mempunyai kata-kata kunci yang hangat, sensitif, penuh penerimaan, ada pengertian dan respon yang tepat pada kebutuhan anak (Garbarino dkk dalam Koentjoro, 2004) .

Sejalan dengan perkembangan masyarakat saat ini, pendidikan banyak mengalami berbagai hambatan. Salah satu hambatan yaitu berkenaan dengan peningkatan mutu pendidikan yang disebabkan rendahnya prestasi belajar anak dan mutu pendidikan. Kegiatan pembelajaran merupakan bagian dari pendidikan dan banyak faktor yang secara langsung menentukan kesuksesan belajar dan keberhasilan pendidikan. Salah satu faktor yang menentukan kesuksesan belajar terletak pada sejauh mana orang tua memberikan bimbingan belajar kepada anak. Menurut Djamarah (2002), "mendidik berarti membimbing dan mengarahkan serta memperhatikan anak kepada kedewasaannya, dewasa secara etis, psikologi dan sosial". Namun, pada kenyataannya banyak orang tua yang tidak selalu bisa memberikan bimbingan belajar yang sepenuhnya kepada anak karena disibukkan dengan kepentingan kerja maupun kepentingan yang lain. Terkadang orang tua banyak mengabaikan perkembangan belajar anak, sehingga anak merasa tidak dibimbing dengan baik. Apabila anak kurang mendapat bimbingan belajar dari orang tua, maka secara tidak langsung dapat berpengaruh terhadap prestasi belajar yang dicapai kurang maksimal. Selain dari bimbingan belajar orang tua yang dapat mempengaruhi prestasi belajar anak, faktor dalam diri anak juga mempengaruhi prestasi belajarnya, baik dilingkungan sekolah maupun dilingkungan luar sekolah. Dilingkungan sekolah misalnya, anak tidak suka terhadap penyampaian yang dilakukan gurunya dalam proses belajar mengajar baik dari segi metode maupun media yang digunakan guru dalam proses belajar. Sikap dan tutur kata guru juga dapat mempengaruhi pandangan anak-anak terhadap pelajaran yang di sampaikan oleh guru. Pandangan tersebut 
maksudnya anak menjadi takut atau merasa dibawah tekanan tiap menghadapi guru tersebut. Dilingkungan luar sekolah misalnya, anak lebih suka bermain bersama temannya ketimbang belajar di rumah.

Dari hasil pra penelitian yang dilakukan oleh penulis, SDN 27 terletak sangat strategis di tengah-tengah kota yaitu berada di jalan Putri Gading Cempaka Penurunan Kecamatan Ratu Samban Kota Bengkulu. SDN 27 Kota Bengkulu memiliki 12 ruang kelas, dimana setiap kelas terdiri dari dua lokal kelas misalnya kelas VI A dan kelas VI B. Di SDN 27 Siswa kelas VI berjumlah 53 siswa terdiri dari Kelas VI A 26 orang dan Kelas VI B 27 Orang. Siswa yang dikatakan berprestasi dikelas pada umumnya merupakan siswa yang masuk rangking 10 besar. Maka dengan itu, peneliti hanya memfokuskan pada bimbingan orang tua kepada anak yang termasuk dalam rangking 3 besar tersebut khususnya dalam pelajaran Matematika. Berdasarkan uraian latar belakang yang telah dijabarkan di atas, maka penulis terdorong untuk melakukan penelitian dengan judul "Komunikasi Orang Tua Pada Anak Dalam Upaya Meningkatkan Prestasi Belajar Matematika“ Studi Pada Orang Tua dan Anak Siswa Kelas VI SDN 27 Kota Bengkulu ".

\section{METODE PENELITIAN}

Penelitian yang digunakan dalam penelitian ini adalah penelitian dengan metode kualitatif. Menurut Denzin dan Linclon (dalam Moleong 2007) penelitian kualitatif merupakan penelitian yang menggunakan latar ilmiah, dengan maksud menafsirkan fenomena yang terjadi dan dilakukan dengan jalan melibatkan berbagai metode yang ada. Tujuan menggunakan metode ini ingin mengungkapkan dan menyajikan apa adanya tentang komunikasi bimbingan orang tua pada anak dalam meningkatkan prestasi belajar matematika pada siswa kelas VI SDN 27 Kota Bengkulu.

Jenis penelitian ini adalah penelitian kualitatif deskriptif. Penelitian tersebut adalah penelitian yang datanya kualitatif.
Data yang disampaikan dalam bentuk verbal, dimana lebih menekankan pada persoalan kontekstual dan tidak terikat dengan perhitungan angka-angka, ukuran yang bersifat empiris. Penelitian kualitatif mengkaji perspektif partisipan dengan strategi-strategi yang bersifat interaktif dan fleksibel. Penelitian kualitatif ditujukan untuk memahami fenomena-fenomena sosial dari sudut pandang partisipan. Dengan demikian arti atau pengertian penelitian kualitatif tersebut adalah penelitian yang digunakan untuk meneliti pada kondisi objek alamiah dimana peneliti merupakan instrumen kunci (Sugiono, 2005).

Penelitian kualitatif tidak mengenal adanya istilah populasi, tetapi oleh Spradley (Sugiono, 2005) dinamakan sosial situation atau situasi sosial yang terdiri dari tiga hal yaitu tempat, pelaku dan aktifitas yang berinteraksi secara sinergis. Selanjutnya menurut Sugiono (2005) sampel dalam penelitian kualitatif bukan dinamakan responden melainkan informan kunci, narasumber, partisipan, teman atau guru dalam penelitian.

Moleong (2007:90) menyatakan bahwa informan adalah orang yang dimanfaatkan untuk memberikan informasi tentang situasi dan kondisi latar penelitian dengan mempergunakan informasi peneliti atau mendapatkan informasi tentang kondisi komunikasi yaitu tentang komunikasi bimbingan orang tua pada anak dalam upaya meningkatkan prestasi belajar matematika. Penelitian informan dalam penelitian ini tidak dilakukan secara acak melainkan berdasarkan tujuan tertentu yaitu disesuaikan dengan sasaran penelitian dan mempergunakan teknik purposive sampling atau dengan teknik sampel yang bertujuan.

Berdasarkan ketentuan diatas maka acuan dasar responden yang akan dijadikan informan dalam penelitian ini adalah:

1. Ibu dan anak

2. Mau meluangkan waktu untuk diminta informasi

3. Mereka yang tidak cenderung menyampaikan informasi hasil kemasannya sendiri. 
Dalam penelitian ini, peneliti menggunakan informan-informan yang terdiri dari:

\section{Informan Pokok}

Informan pokok yaitu tokoh masyarakat yang memberikan informasi sebagian besar mengenai komunikasi orang tua pada anak dalam upaya meningkatkan prestasi belajar Matematika. Informan pokok dalam penelitian ini yaitu ibu dan anak sebanyak 4 orang, yaitu terdiri dari 2 orang ibu dan 2 orang anak dari masingmasing anak dari kelas VI A satu orang dan kelas VI B satu orang yang masuk kedalam rangking 10 besar di SDN 27 Penurunan Kota Bengkulu.

\section{Informan Kunci}

Informan kunci yaitu seseorang yang secara lengkap dan mendalam mengetahui informasi yang akan menjadi permasalahan dalam penelitian. Informan kunci dalam penelitian ini yaitu Guru Matematika SDN 27 Penurunan Kota Bengkulu Ibu Zuliarti, S.Pd.

Data dalam penelitian ini dikumpulkan dengan beberapa metode, yaitu: wawancara terstruktur, observasi, dan dokumentasi. Sedangkan analisis data dilakukan dalam tiga komponen pokok meliputi reduksi data, sajian data, dan penarikan kesimpulan dengan verifikasinya (Sutopo, 2002). Dalam penelitian ini, peneliti menggunakan model analisis interaktif. Pada dasarnya model analisis interaktif proses berbentuk siklus, yang artinya pada bentuk ini peneliti tetap bergerak diantara tiga komponen analisis dengan poses pengumpulan data selama kegiatan pengumpulan berlangsung.

\section{HASIL PENELITIAN DAN \\ PEMBAHASAN \\ Profil Informan}

Berdasarkan pengambilan data penelitian yang dilaksanakan dari tanggal 21 Maret s/d 21 April 2016, dalam penelitian ini penulis menggunakan informan kunci sebanyak 1 orang yaitu Guru matematika Sekaligus walikelas VI A SDN 27 Kota Bengkulu yaitu Ibu Zuliarti,S.Pd, dimana guru tersebut mengetahui dan memahami semua peningkatan belajar Matematika yang dilakukan oleh siswa kelas VI SDN 27 Kota Bengkulu. Sedangkan informan pokok dalam penelitian ini adalah Orang Tua dan anak siswa kelas VI SDN 27 kota Bengkulu sebanyak 2 orang tua siswa dan 2 orang anak masing-masing dari Kelas VI A 1 orang dan Kelas VI B 1 orang. Berikut tabel karekteristik informan kunci dan informan pokok dapat dilihat pada tabel dibawah ini:

Tabel 1 Karakteristik Informan Kunci

\begin{tabular}{|l|l|l|c|}
\hline No. & Nama & \multicolumn{1}{|c|}{ Pekerjaan } & $\begin{array}{l}\text { Masa } \\
\text { Kerja }\end{array}$ \\
\hline 1. & Zuliarti, & $\begin{array}{l}\text { Guru Matematika } \\
\text { dan Walikelas VI } \\
\text { S.Pd }\end{array}$ & 23th \\
& & $\begin{array}{l}\text { SDN 27 Kota } \\
\text { Bengkulu }\end{array}$ & \\
\hline
\end{tabular}

Ibu Zuliarti, S.Pd adalah Guru Matematika sekaligus Walikelas VI A SDN 27 Kota Bengkulu. Ibu Zuliarti ditahun 2016 ini menginjak usia 48 tahun dan kurang lebih sudah 23 tahun menjadi Guru Matematika di SDN 27 Kota Bengkulu. Masa kerja yang sudah cukup lama Ibu Zuliarti mendapat gambaran mengenai karakter anak khususnya anak kelas VI seperti yang rajin belajar, malas belajar dan yang suka bermain-main serta cara mengatasinya.

Tabel 2 Karakteristik Informan Pokok

\begin{tabular}{|c|l|l|l|l|}
\hline No & \multicolumn{1}{|c|}{$\begin{array}{c}\text { Nama } \\
\text { Siswa }\end{array}$} & $\begin{array}{c}\text { Nama } \\
\text { Orang } \\
\text { Tua }\end{array}$ & $\begin{array}{c}\text { Pendidikan } \\
\text { Orang Tua }\end{array}$ & $\begin{array}{c}\text { Pekerjaan } \\
\text { Orang } \\
\text { Tua }\end{array}$ \\
\hline 1. & $\begin{array}{l}\text { Resyaliana } \\
\text { Esa Putri }\end{array}$ & $\begin{array}{l}\text { Desi } \\
\text { Yanti }\end{array}$ & SLTA & IRT \\
\hline 2. & $\begin{array}{l}\text { Zaky M. } \\
\text { Putra }\end{array}$ & $\begin{array}{l}\text { Lini } \\
\text { Marlina }\end{array}$ & SLTA & IRT \\
\hline
\end{tabular}


Resyaliana adalah siswi berprestasi di kelas VI A SDN 27 Kota Bengkulu. Resyaliana mendapat rangking 1 dari 27 siswa dengan nilai matematika 90. Resyaliana dikenal sebagai siswi yang mudah bergaul dan rajin belajar, untuk itu Resyaliana layak untuk penulis teliti. Resyaliana anak pertama dari ibu Desi Yanti yang tinggal di Jalan Putri Gading Cempaka Penurunan Depan BIM.

Zaky Muhammad Putra adalah siswa berprestasi di Kelas VI B SDN 27 Kota Bengkulu. Zaky mendapat rangking 1 dari 26 siswa dengan nilai matematika 90. Zaky dikenal sebagai siswa yang pendiam dan suka membaca komik. Zaky anak ke tiga dari Ibu Lini Marlina yang tinggal di Jalan Putri Gading Cempaka Penurunan. Dari keterangan di atas Zaky layak untuk penulis teliti

\section{Hasil Penelitian}

Dalam penelitian ini, peneliti melakukan wawancara ke Guru Matematika sekaligus walikelas VI A SDN 27 Kota Bengkulu tentang komunikasi Orang Tua pada anak dalam upaya meningkatkan prestasi belajar Matematika. Komunikasi yang digunakan dalam penelitian ini yaitu komunikasi instruksional yang mengarah kepada komunikasi parenting Guru-orang tua, Guru-Siswa dan orang tua-siswa. Komunikasi instruksional berasal dari kata instruction (perintah), di dunia pendidikan kata instruksional tidak diartikan perintah tetapi pengajaran dan pembelajaran. Didalam pendidikan komunikasi instruksional adalah proses penyampaian pesan dalam pembelajaran ke pihak sasaran untuk mengubah perilaku atau hasil yang ingin dicapai dalam belajar. Komunikasi instruksional yang digunakan dalam komunikasi orang tua pada anak ini melalui tiga tahap instruksional yaitu tahap prainstruksional, tahap instruksional dan tahap evaluasi atau tindak lanjut.

\section{Tahap Prainstruksional}

Ditahap ini ada beberapa hal yang memerlukan rancangan dalam proses belajar dan mengajar seperti mengarahkan dan dapat secara langsung melihat perilaku awal anak ketika di arahkan untuk belajar.

Berikut jawaban dari Ibu Zuliarti, S.Pd mengenai cara mengarahkan siswa belajar Matematika di SDN 27 Kota Bengkulu:

“...Sebelum pelajaran dimulai saya mengarahkan siswa untuk diam dan mendengarkan apa yang akan saya jelaskan, supaya siswa mengerti dengan apa yang saya sampaikan" (hasil wawancara pada tanggal 15 April 2015).

Ibu Zuliarti,S.Pd juga mengungkapkan perilaku awal siswa ketika diarahkan belajar Matematika yaitu:

“...Sejauh ini siswa mengikuti apa yang saya arahkan, biasanya saya juga memberikan pilihan bagi yang tidak mau belajar boleh keluar dari kelas agar tidak mengganggu teman yang lain" (hasil wawancara pada tanggal 15 April 2015).

Berdasarkan hasil wawancara tahap prainstruksional mengarahkan siswa belajar matematika yaitu dengan mengarahkan anak untuk diam dan mendengarkan apa yang dijelaskan guru dan perilaku awal siswa ketika belajar Matematika disekolah adalah mengikuti apa yang diperintahkan oleh guru.

Ibu Desi juga mengungkapkan mengarahkan anak belajar Matematika di rumah yaitu:

“...ketika anak pulang sekolah saya mengarahkan anak untuk bergegas ganti pakaian kemudian makan dan dilanjutkan tidur siang, sore saya memperbolehkan anak untuk bermain bersama temannya, habis magrib saya mengarahkan anak saya untuk belajar mengulangi pelajaran Matematika yang dipelajari di sekolah" (hasil wawancara pada tanggal 12 April 2016).

Ibu Desi juga mengungkapkan bagaimana perilaku awal anaknya ketika ketika diarahkan untuk belajar Matematika sebagai berikut: 
“...sejauh ini apa yang saya terapkan diikuti oleh anak saya, saya juga selalu mengawasi apa yang dilakukan oleh anak saya" (hasil wawancara dengan Ibu Desi Yanti pada tanggal 12 April 2016).

Berdasarkan hasil wawancara tahap prainstruksional Ibu Desi mengarahkan anak untuk belajar Matematika dengan cara mengarahkan anak untuk mengulangi pelajaran yang ada di sekolah dan perilaku awal anak ketika belajar Matematika dirumah mengikuti perintah orang tuanya untuk belajar.

Resyaliana juga menjelaskan cara ibunya mengarahkan belajar Matematika di rumah, yaitu:

"...Ibu selalu mengarahkan saya untuk belajar mengulangi pelajaran disekolah, supaya saya tidak lupa apa yang dipelajari di sekolah. Jam belajar saya sesudah magrib sampai isya, selama jam belajar saya tidak boleh nonton $T V$ ' (hasil wawancara pada tanggal 14 april 2016).

Resyaliana juga mengatakan perilaku awalnya ketika ibunya mengarahkan untuk belajar Matematika adalah:

“...saya selalu mengikuti apa yang ibu katakan untuk belajar, agar saya dapat mempertahankan peringkat saya dikelas, saya ingin bikin ibu bangga" (hasil wawancara pada tanggal 14 april 2016).

Berdasarkan hasil wawancara tahap prainstruksional cara ibu Resyaliana mengarahkan belajar Matematika di rumah dengan mengarahkan untuk belajar mengulangi pelajaran di sekolah. Perilaku awal Resyaliana pada saat diarahkan untuk belajar Matematika adalah mengikuti agar Resyaliana dapat mempertahankan peringkatnya di kelas.

Berikut jawaban Ibu Lini Marlina dalam mengarahkan anak belajar Matematika dirumah yaitu:

"...saya mengarahkan anak untuk belajar sesudah magrib, kalau sore anak saya sibuk mengaji dan bermain bersama temannya. Saya menyuruh anak saya untuk mengulangi pelajaran di sekolah agar anak saya tidak lupa apa yang dijelaskan oleh gurunya" (hasil wawancara pada tanggal 13 April 2016).

Ibu Lini juga mengungkapkan perilaku awal anaknya ketika diarahkan untuk belajar adalah:

"...Anak saya mengikuti untuk belajar dirumah, meskipun kadangkadang Bukunya hanya dibuka saja dan matanya suka ke mana-mana" (hasil wawancara dengan Ibu Lini Marlina pada tanggal 13 April 2016). Berdasarkan hasil wawancara tahap prainstruksional dari Ibu Lini Marlina mengarahkan anak untuk belajar dengan cara mengarahkan anak untuk belajar sesudah magrib dan menasihatinya. Perilaku awal anak ketika diarahkan untuk belajar anaknya mengikuti meskipun kadangkadang membantah.

Berikut jawaban Zaky mengenai cara ibunya mengarahkan untuk belajar Matematika dirumah adalah:

“...ibu menyuruh saya untuk belajar mengulangi pelajaran di sekolah. Jam belajar saya sesudah magrib, terkadang saya tidak belajar tetapi membaca komik, karena saya suka membaca komik seperti komik konan" (hasil wawancara pada tanggal 14 april 2016).

Zaky juga menjelaskan perilaku awalnya ketika diarahkan untuk belajar Matematika yaitu:

“...saya mengikuti untuk belajar, kadang-kadang tidak. Saya pergi ke kamar untuk membaca komik. Ibu suka marah kalau saya tidak belajar, takut nilai saya turun" (hasil wawancara pada tanggal 14 april 2016).

Berdasarkan hasil wawancara tahap prainstruksional cara Ibu zaky mengarahkan belajar Matematika di rumah dengan mengarahkan untuk belajar. Perilaku awal zaky pada saat diarahkan untuk belajar 
adalah mengikuti meskipun kadang-kadang membantah.

Hasil dari observasi pada tahap prainstruksional mengarahkan anak untuk belajar yaitu mulai dari membimbing anak dari pulang sekolah, mengatur pola makan, memperhatikan kebutuhan bermain dan tidur anak hingga menyuruh anak untuk belajar mengulangi pelajaran disekolah supaya anak tidak lupa apa yang telah diajarkan disekolah perilaku awal anak mengikuti apa yang diarahkan oleh orang tua meskipun ada waktunya anak-anak membantah untuk tidak belajar, itu dikarenakan anak merasa jenuh untuk belajar.

\section{Tahap Instruksional}

Tahap ini adalah tahap menjalankan pembelajaran, mulai dari menyiapkan kebutuhan belajar dan mengajar sampai pada cara yang diterapkan dalam proses belajar.

Berdasarkan pemahaman diatas, Ibu Zuliarti menjelaskan kebutuhan yang dia berikan dalam menunjang belajar Matematika di Sekolah adalah:

“...Demi kelancaran dalam proses belajar disekolah saya menggunakan alat peraga seperti bangun ruang, supaya anak lebih memahami dan Sekolah juga menyediakan buku panduan Matematika untuk kelas VI penerbit Erlangga, siswa dianjurkan untuk membeli bagi yang tidak mampu boleh fhoto kopi punya temannya dan sekolah juga menyediakan LKS untuk belajar dirumah" (hasil wawancara pada tanggal 15 April 2015).

Ibu Zuliarti, S.Pd juga menjelaskan cara yang digunakan dalam belajar Matematika di sekolah yaitu:

"...Saya mengajar dengan cara ceramah, diskusi dan mempraktekan langsung. Dimana saya menerangkan didepan kelas dan mempraktekan pengerjaan soal Matematika dipapan tulis sedangkan siswa mendengarkan dan mencatat contoh pengerjaan yang saya berikan, siswa juga ada yang saya tunjuk untuk mempraktekkan langsung pengerjaan soal dipapan tulis" (hasil wawancara pada tanggal 15 April 2015).

Berdasarkan dari hasil wawancara tahap instruksional mengenai kebutuhan apa yang di berikan dalam menunjang belajar siswa yaitu menggunakan alat praga seperti bangun ruang dan menganjurkan siswa untuk membeli buku panduan Matematika penerbit Erlangga dan buku LKS yang disediakan oleh pihak sekolah serta cara yang digunakan dalam mengajar Matematika di kelas adalah dengan ceramah, diskusi dan mempraktekkan langsung cara pengerjaan soal Matematika sebagai contoh untuk pengerjaan soal berikutnya.

Lain halnya dengan jawaban yang diberikan ibu Desi Yanti mengenai kebutuhan apa saja yang diberikan dalam menunjang belajar Matematika anak dirumah, ibu Desi mengatakan:

“...saya membelikan buku pelajaran Matematika, biasanya disekolah menyediakan buku panduannya dan anak saya meminta untuk dibelikan, saya sebagai orang tua demi kemajuan anak saya belikan meskipun harga buku tersebut mahal, saya selalu usahakan untuk kebutuhan anak" (hasil wawancara pada tanggal 12 April 2016).

Ibu desi Yanti juga menjelaskan cara yang digunakan dalam mengajar Matematika di rumah adalah:

“...biasanya jika anak saya kesulitan mengerjakan soal dia bertanya kepada saya dan saya memberitahu rumus-rumus dengan contoh yang lain, saya selalu menerapkan cara berdiskusi kepada anak saya, agar anak saya mengetahui apa yang saya sampaikan, misalnya contoh soal hasil dari 60: $(-7+13)-(-26)$, anak saya suka lupa kalu pengurangan ketemu min hasilnya plus, tapi untuk saat ini anak saya 
sudah bisa mengerjakannya" (hasil wawancara pada tanggal 12 April 2016).

Berdasarkan hasil wawancara tahap instruksional mengenai kebutuhan yang diberikan Ibu Desi membelikan buku panduan Matematika dan cara yang digunakan Ibu Desi mengajar Matematika dengan cara diskusi.

Resyaliana juga mengatakan kebutuhan apa saja yang ibunya berikan dalam menunjang belajar Matematika di rumah.

“...Ibu membelikan buku yang saya butuhkan, walaupun ibu suka telat untuk membayar, selain itu ibu juga menyiapkan alat tulis lainya misalnya pena, penggaris agar saya semangat untuk belajar" (hasil wawancara pada tanggal 14 april 2016)

Resyaliana juga menceritakan cara yang ibunya gunakan dalam mengajar Matematika di rumah yaitu:

"...Ibu memberitahu cara pengerjaan soal-soal yang sulit, ibu tidak mendapingi selama belajar, ibu hanya melihat saat saya bertanya dan memberitahu cara pengerjaannya" (hasil wawancara pada tanggal 14 april 2016).

Berdasarkan hasil wawancara tahap instruksional kebutuhan yang diberikan dalam menunjang belajar Matematika Resya menjawab membelikan buku Matematika dan alat tulis. Cara ibu Resya dalam mengajar Matematika yaitu memberitahu pengerjaan soal-soal yang sulit tetapi tidak mendampingi selama Resya belajar.

Ibu Lini Marlina juga menjawab dan menjelaskan Kebutuhan apa saja yang diberikan dalam menunjang belajar Matematika anak di rumah:

“...saya menyediakan meja belajar khusus untuk anak saya, supaya tidak terganggu belajarnya dan membelikan buku panduan yang ada disekolah serta menyiapkan kebutuhan lainnya seperti alat tulis" (hasil wawancara pada tanggal 13 April 2016).

Ibu Lini juga Menjelaskan cara yang digunakan dalam mengajar Matematika di rumah:

“...saya memberitahu saja yang anak saya tanya, kalau tidak bertanya berarti anak saya mengerti. Misalkan ada soalnya yang sulit sayapun tidak dapat membantu cara pengerjaannya saya bertanya kepada tetangga saya kebetulan guru Matematika SMP misalkan contoh soal yang saya tidak mengerti jarak dua kota kediri dan madiun adalah $380 \mathrm{~km}$, sebuah bus berjalan dari kota kediri ke kota madiun dengan kecepatan $80 \mathrm{~km} / \mathrm{jam}$, jika bus tiba pada pukul 11.30, maka bus berangkat pada pukul?, soal seperti ini yang saya kurang pahami" (hasil wawancara pada tanggal 13 April 2016).

Berdasarkan hasil wawancara tahap instruksional dalam menunjang belajar Matematika di rumah Ibu Lini menyediakan meja belajar khusus untuk anaknya supaya belajar anaknya tidak terganggu dan menyediakan kebutuhan lainnya seperti buku. Dalam mengajar Matematika di rumah Ibu Lini menjelaskan saja yang anaknya tanya dan membantu anak bertanya kepada orang lain dalam mengerjakan soal yang sulit.

Zaky juga mengungkapkan kebutuhan apa saja yang ibunya berikan dalam menunjang belajar Matematik di rumah:

“...Sebelum belajar ibu selalu menyiapkan kebutuhan belajar saya seperti tempat belajar, buku dan alat tulis" (hasil wawancara pada tanggal 14 april 2016).

Zaky juga menceritakan cara yang ibu gunakan dalam mengajar Matematika dirumah yaitu:

“...ibu menjelaskan kalau saya bertanya, kalau ibu tidak tahu menyuruh saya bertanya sama ibu guru tetangga kami, ibu tidak 
mendampingi saya selama belajar tetapi ibu saya selalu mengawasi saya untuk belajar, ibu kurang memahami soal-soal cerita" (hasil wawancara pada tanggal 14 april 2016).

Berdasarkan hasil wawancara tahap instruksional kebutuhan yang diberikan dalam menunjang belajar Matematika zaky menjawab menyiapkan kebutuhan belajar seperti tempat belajar, buku dan alat tulis. Cara ibu zaky dalam mengajar Matematika yaitu menjelaskan yang zaky tanya, kalu ibu zaky tidak tahu menyuruh zaky bertanya pada ibu guru Matematika tetangga zaky dan ibu Zaky tidak mendampingi selama belajar tetapi mengawasi saja agar Zaky Belajar bukan bermain atau membaca komik.

Hasil observasi dari tahap instruksional ini yaitu mengenai kebutuhan yang diberikan dalam menunjang belajar Matematika dirumah orang tua selalu mengatur jam belajar anak dan menyiapkan buku panduan dari sekolah dan alat tulis seperti pensil, penghapus serta penggaris. Cara yang digunakan orang tua dalam mengajar Matematika dirumah menjelaskan jika anaknya bertanya, jika ibu tidak tahu mengenai soal Matematika ibu meminta bantuan dari tetangga yang bisa Matematika.

\section{Tahap Evaluasi dan Tindak Lanjut}

Tahap ini dilakukan untuk mengetahui tingkat keberhasilan anak dalam meningkatkan prestasi belajar. Bagi anak yang belum memenuhi kriteria pencapaian tujuan yang telah ditetapkan, hendaknya disiapkan rancangan khusus agar anak dapat meningkatkan prestasi belajarnya.

Mengenai cara mengetahui peningkatan prestasi belajar matematika siswa di sekolah Ibu Zuliarti mengungkapkan:

“...Saya dapat mengetahui peningkatan belajar Matematika siswa dari nilai harian dan ulangan siswa, kalau nilai rata-ratanya bagus berarti siswa sudah memahami apa yang saya sampaikan dan diajarkan" (hasil wawancara pada tanggal 15 April 2015).

Ibu Zuliarti, S.Pd juga mengatakan jika siswa belum meningkatkan prestasi belajar Matematika di sekolah, upaya yang lakukan yaitu:

“...Saya selalu memberikan motivasi dan pujian kepada mereka supaya mereka selalu meningkatkan belajarnya. Saya sering memberikan pesan kepada siswa jangan hanya belajar dikelas saja namun ketika dirumah harus mengulangi pelajaran yang diajarkan disekolah dan mengikuti les tambahan diluar jam sekolah. Supaya pada saat mengerjakan soal latihan atau ulangan siswa sudah siap mengerjakannya" (hasil wawancara pada tanggal 15 April 2015).

Berdasarkan hasil wawancara tahap evaluasi atau tindak lanjut mengenai cara mengetahui peningkatan belajar Matematika siswa adalah dengan melihat nilai harian dan ulangan siswa, jika nilai rata-rata siswa bagus berarti mereka mengerti apa yang diajarkan. Upaya peningkatan prestasi belajar Matematika di Sekolah, guru memberikan motivasi dan pujian kepada mereka supaya mereka selalu meningkatkan prestasinya dan siswa juga dipesankan untuk mengulang pelajaran dirumah.

Ibu Desi Yanti juga mengungkapkan mengenai cara mengetahui peningkatan prestasi belajar Matematika anak disekolah yaitu:

“...saya selalu melihat buku dan nilai anak saya setiap hari, jika nilainya jelek saya tidak memperbolehkan anak saya keluar rumah, kalau bagus alhamdulillah, saya memperbolehkan anak saya bermain tetapi ada batasnya" (hasil wawancara pada tanggal 12 April 2016).

Jika anak belum meningkatkan prestasi belajar Matematika di sekolah, upaya yang dilakukan Ibu Desi Yanti adalah: 
“...saya akan memarahi anak saya dan jika rezekinya ada saya akan mencarikan tempat les tambahan untuk anak saya" (hasil wawancara dengan pada tanggal 12 April 2016).

Berdasarkan hasil wawancara tahap evaluasi atau tindak lanjut mengenai cara mengetahui peningkatan belajar Matematika anak disekolah yaitu dengan melihat nilai anak setiap hari. Upaya yang di lakukan Ibu Desi dalam peningkatan prestasi belajar Matematika di Sekolah ibu Desi mencarikan tempat les untuk anaknya.

Cara ibu mengetahui peningkatan belajar di sekolah Resyaliana mengatakan:

“...Ibu selalu memeriksa buku saya setiap hari, kalau ada nilai saya yang jelek saya tidak diperbolehkan keluar rumah apalagi bermain bersama teman" (hasil wawancara pada tanggal 14 april 2016).

Jika belum meningkatkan prestasi belajar Matematika di sekolah, upaya apa yang ibu lakukan Resya menjawab:

“...biasanya jika nilai saya menurun ibu selalu memarahi saya, mungkin jika ibu ada uang ibu akan mencarikan tempat les tambahan untuk saya" (hasil wawancara pada tanggal 14 april 2016).

Berdasarkan hasil wawancara tahap evaluasi dan tindak lanjut, cara mengetahui peningkatan belajar Matematika disekolah adalah ibu Resya melihat dan memeriksa nilai harian Resya dan jika Resya belum meningkatkan prestasi belajar Ibu Resya akan mencarikan tempat les untuk Resya.

Ibu Lini Marlina juga mengatakan cara mengetahui peningkatan prestasi belajar Matematika anak disekolah yaitu :

“...saya melihat nilai ulangan anak saya, jika nilainya meningkat dari yang ulangan kemarin berarti anak saya sudah dapat memahami mengenai pelajaran Matematikanya disekolah" (hasil wawancara pada tanggal 13 April 2016).

Jika anak belum meningkatkan prestasi belajar Matematika di sekolah, upaya yang dilakukan Ibu Lini Marlina adalah:

“...saya selalu memberi motivasi kepada anak saya untuk terus belajar dan saya juga akan mencarikan tempat les tambahan untuk anak saya dan membelikan buku-buku pedoman Matematika lainnya agar nantinya anak saya bisa lulus dengan nilai yang baik" (hasil wawancara pada tanggal 13 April 2016).

Berdasarkan hasil wawancara tahap evaluasi atau tindak lanjut mengenai cara mengetahui peningkatan prestasi belajar Matematika disekolah Ibu Lini selalu melihat nilai ulangan Zaky dan upaya peningkatan prestasi belajar Matematika di Sekolah Ibu Lini akan mencarikan tempat les tambahan dan membelikan buku pedoman Matematika Lainnya.

Zaky juga menjawab pertanyaan mengenai cara ibu Zaky mengetahui peningkatan prestasi belajar disekolah yaitu:

“...ibu selalu melihat nilai ulangan Zaky, jika nilai Zaky menurun Ibu selalu memarahi Zaky dan tidak memperbolehkan Zaky bermain dan membaca komik" (hasil wawancara pada tanggal 14 april 2016).

Zaky juga menjelaskan jika belum meningkatkan prestasi belajar Matematika di sekolah, upaya yang dilakukan ibu Zaky adalah:

“...Ibu biasanya memberi semngat kepada saya agar saya tidak mudah putus asa dan ibu juga mencarikan tempat les tambahan untuk saya" (hasil wawancara pada tanggal 14 april 2016).

Berdasarkan hasil wawancara tahap evaluasi dan tindak lanjut, cara ibu Zaky mengetahui peningkatan prestasi belajar Zaky disekolah dengan cara melihat nilai ulangan Zaky, jika Zaky belum meningkatkan prestasi belajar disekolah Ibu Zaky akan mencarikan tempat les tambahan.

Dari hasil observasi pada tahap evaluasi dan tindak lanjut mengenai cara orang tua mengetahui peningkatan prestasi 
belajar Matematika di sekolah yaitu orang tua selalu memeriksa buku anaknya setelah pulang sekolah dan melihat nilai harian maupun nilai ulangan anak. Upaya yang dilakukan orang tua jika anaknya belum meningkatkan prestasi belajar matematika di sekolah yaitu mencarikan anaknya tempat les tambahan.

\section{Pembahasan}

Berdasarkan hasil dari penelitian dalam hal mencapai suatu kesimpulan benar dan objektif, peneliti akan melakukan konfirmasi dan analisa dari beberapa data yang telah ditemukan dilapangan dengan pemantauan secara langsung ke rumah informan pokok dan ke Sekolah Dasar Negeri 27 Kota Bengkulu.

Komunikasi orang tua pada anak dalam upaya meningkatkan prestasi belajar Matematika di rumah merupakan tindakan atau perilaku untuk mempengaruhi anak pada proses belajar untuk mencapai prestasi belajar yang telah ditetapkan. Di rumah komunikasi orang tua dalam memberikan bimbingan belajar kepada anak sudah diterapkan, seperti mengarahkan anak untuk belajar mengulangi pelajaran di sekolah, agar anak dapat lebih memahami dan mengerti rumus-rumus Matematika yang digunakan. Perilaku awal anak ketika ibu mengarahkan untuk belajar Matematika adalah mengikuti perintah ibunya, meskipun ada waktunya anak-anak membantah dan lebih suka bermain bersama temantemannya atau menonton TV. Hal ini sering disebabkan anak merasa jenuh untuk belajar, oleh karena itu sebagai orang tua harus lebih memperhatikan dan mempunyai sesuatu hal yang membuat anak tidak jenuh.

Pada tahap prainstruksional ini sudah berjalan cukup baik, yaitu mengarahkan anak untuk belajar mengulangi pelajaran di sekolah dan perilaku awal anak mengikuti pada saat diarahkan untuk belajar meskipun kadang-kadang membantah.

Kebutuhan yang diberikan dalam menunjang belajar Matematika di rumah sangat minim, hanya buku panduan dan LKS. Padahal kebutuhan dalam menunjang belajar sangat penting bagi anak untuk meningkatkan prestasi belajar di sekolah, karena dapat membangkitkan motivasi belajar anak dan mempertinggi daya serap anak. Dalam mengajar Matematika di rumah cara yang digunakan dalam proses belajar adalah dengan menjelaskan. Dimana anak tidak memahami soal Matematika dan bertanya kepada ibu, sedangkan ibu hanya menjelaskan saja cara pengerjaan dan mendapatkan hasilnya tanpa mendampingi anak dalam proses belajar. Orang tua tidak hanya menjelaskan saja tetapi menggunakan cara yang bervariasi seperti berdiskusi, tanya jawab agar proses berfikir anak terbuka dan mudah mengingat serta mendampingi anak dalam proses belajar agar anak benar-benar belajar. Jika orang tua tidak tahu mengenai pengerjaan soal Matematika yang sulit orang tua harus mempunya alternatif lain yaitu bertanya kepada tetangga yang mengerti Matematika.

Pada tahap instruksional dalam proses belajar di rumah yang dilakukan oleh orang tua pada anak belum berjalan sepenuhnya, karena kebutuhan anak dalam menunjang belajar anak di rumah kurang diperhatikan hanya berbekal buku panduan dan LKS saja dan cara mengajarnyapun menjelaskan saja yang anak tanya tanpa melakukan proses tanya jawab terlebih dahulu agar proses berfikir anak lebih terbuka.

Cara mengetahui peningkatan prestasi belajar Matematika anak disekolah yaitu dengan melihat nilai harian dan ulangan anak, orang tua selalu mengecek perkembangan nilai harian anak. Jika anak belum meningkatkan prestasi belajar Matematika di sekolah, upaya yang dilakukan orang tua yaitu akan mencarikan tempat les tambahan. Sebaiknya orang tua tidak hanya mencarikan tempat les tambahan melainkan memberikan motivasi dan pujian supaya anak meningkatkan prestasi belajarnya dan juga memperhatikan kebutuhan lainnya seperti asupan gizi anak serta kebutuhan bermain anak. Jangan larang anak untuk bermain tetapi aturlah 
jadwalnya dengan baik agar anak tidak merasa jenuh.

Pada tahap evaluasi dan tindak lanjut dalam proses belajar yang dilakukan di rumah sudah berjalan cukup baik yaitu menilai peningkatan belajar anak melalui nilai harian dan ulangan anak, orang tua selalu mengecek buku anak ketika pulang sekolah dan upaya yang dilakukan orang tua dalam meningkatkan prestasi belajar anak tidak hanya mencarikan tempat les tambahan melainkan juga memberikan motivasi dan dorongan kepada anak untuk jangan malas belajar serta memberikan hadiah kepada anak jika anak dapat meningkatkan prestasinya di sekolah.

\section{PENUTUP}

\section{Kesimpulan}

Dari hasil penelitian dan pembahasan Peran komunikasi instruksional orang tua pada anak dalam upaya meningkatkan prestasi belajar Matematika maka ditarik kesimpulan antara lain sebagai berikut:

1. Tahap prainstruksional dalam komunikasi orang tua pada anak dalam upaya meningkatkan prestasi belajar Matematika berjalan cukup baik, dimana orang tua mengarahkan anak untuk belajar mengulangi pelajaran di sekolah, sedangkan prilaku awal anak mengikuti meskipun kadang-kadang membantah.

2. Tahap instruksional orang tua pada anak belum berjalan sepenuhnya, dikarenakan kebutuhan dalam menunjang belajar anak kurang diperhatikan dan cara mengajarnyapun hanya menjelaskan tanpa ada proses tanya jawab agar proses berfikir anak terbuka serta orang tua tidak mendampingi selama anak belajar.

3. Tahap evaluasi dan tindak lanjut berjalan cukup baik dimana orang tua mengetahui peningkatan prestasi belajar Matematika dengan melihat nilai harian dan ulangan anak serta upaya yang dilakukan dalam meningkatkan prestasi belajar Matematika adalah mencarikan tempat les tambahan.

\section{Saran}

Berdasarkan hasil penelitian dan kesimpulan, maka penulis memberikan saran-saran sebagai berikut:

1. Diharapkan kepada orang tua untuk mendampingi anak selama belajar agar anak benar-benar belajar.

2. Kepada guru Matematika Sebaiknya dalam mengajar gunakanlah cara bermain sambil belajar agar siswa tidak merasa jenuh.

3. Pada anak harus meningkatkan lagi rasa percaya diri agar aktif dalam bertanya dan menjawab dalam belajar.

\section{DAFTAR PUSTAKA}

Ahmadi. (2005). Psikologi Belajar. Jakarta: Rineka Cipta.

Andayani \& Koentjoro. (2004). Psikologi Keluarga: Coparenting. Yogyakarta: Citra Media.

Atmajaya, Endang. (2015). Komunikasi Orang Tua \& Anak Dalam Upaya Meningkatkan Prestasi Belajar Anak (Analisis Komunikasi Interpesonal Ibu dan Anak Di Perumahan Komplek Selatan Kel. Gading Cempaka Kota Bengkulu).

Azwar, Syaifuddin. (2011). Pembelajaran Matematika. Jakarta: Graha Ilmu.

Bungin, B. (2003). Analisis Data Penelitian Kualitatif. Jakarta: PT Raja Grafindo Persada.

Dahar. (2003). Teori-Teori Belajar. Bandung: Erlangga.

Dalyono. (2005). Psikologi Pendidikan. Jakarta: PT Rineka Cipta.

Djamara. (2005). Strategi Belajar Mengajar. Jakarta: Rineka Cipta.

Djamarah, Syaiful Bahri. (2002). Strategi Belajar Mengajar. Jakarta: Rineka Cipta.

Effendy, Onong. (2003). Ilmu Komunikasi Teori dan Praktek. Bandung: PT Remaja RosdaKarya.

Effendy, Onong Uchjana. (2006). Ilmu Komunikasi Teori Dan Praktek. Bandung: Remaja Rosdakarya. 
Iriantara, Yosal Dan Usep. (2013). Komunikasi Pendidikan. Jakarta: Simbiosa Rekatama Media.

Moleong. (2007). Metode Penelitian Kualitatif. Edisi revisi. Bandung: PT Remaja Rosdakarya.

Muhammad. (2004). Psikologi. Jakarta: Bumi Aksara.

Mulyana. (2000). Ilmu Komunikasi Suatu Pengantar. Bandung: PT Remaja Rosda Karya.

M. Yusup, Pawit. (2010). Komunikasi Instruksional Teori Dan Praktrik. Jakarta: PT Bumi Aksara.

Purwanto. (2007). Metodologi Penelitian Kuantitatif. Yogyakarta: Pustaka Belajar.

Suhendi, Hendi Dan Ramdani Wahyu. (2001). Pengantar Studi Sosiologi Keluarga. Bandung: Pustaka Setia.
Sutopo, H.B. (2002). Metodologi Penelitian Kualitatif. Edisi Ke-1. Surakarta: Sebelas Maret University Press.

Sugiono. (2005). Metode Penelitian Kualitatif, Kuantitatif dan $R \& D$. Bandung: ALFABETA.

Syah, Muhibbin. (2006). Psikologi Belajar. Jakarta: PT Raja Grafindo Persada.

Wuriyanti, Niken. (2010). Optimalisasi Peran Orang Tua Dalam Pengerjaan Tugas Rumah Untuk Meningkatkan Hasil Belajar Matematika Pada Siswa Kelas III SD Negeri 04 Kuto.

Yusuf, Syamsu. (2007). Psikologi Komunikasi Anak Dan Remaja. Bandung: Remaja Rosdakarya.

Zulhakim, Haris. (2014). Peran Komunikasi Instruksional Guru Dalam Peningkatan Hasil Belajar Biasa. 